\title{
PERSEPSI ETNIS TIONGHOA TERHADAP PEMBERITAAN MEDIA TELEVISI TENTANG KANDIDAT CALON PRESIDEN DAN WAKIL PRESIDEN PEMILU 2019
}

\author{
Sutrisno \\ Program Studi Ilmu Komunikasi Buddha \\ Sekolah Tinggi Agama Buddha Negeri Raden Wijaya \\ Wonogiri-Jawa Tengah \\ dutaarya25@gmail.com
}

\begin{abstract}
Abstrak
Pertarungan politik menjadi sebuah kajian penelitian yang sangat menarik untuk dikaji dengan berbagai bidang ilmu untuk mengetahui dan melihat bagaimana perkembangan politik yang ada di Indonesia. Indonesia memiliki keberagaman yang begitu besar dan memiliki etnis yang juga menjadi bagian dari pertarungan politik yang melibatkan masyarakat dengan berbagai etnis, penelitian ini menitik beratkan bagaimana persepsi etnis Tionghoa yang ada di wilayah Surakarta Khususnya di Tempat Ibadah Tridharma Poo An Kiong berkaitan dengan pemberitaan Media Televisi berkaitan dengan Kandidat Calon Presiden dan Wakil Presiden tahun 2019. Metode yang digunakan dalam penelitian ini adalah pendekatan Kualitatif yang melihat bagaimana persepsi Etnis Tionghoa berkaitan dengan Pemberitaan kandidat yang di beritakan oleh media televisi. Study kalayak digunakan dalam penelitian ini dengan pertimbangan melihat kedalaman kalayak dalam menangkap berita dan mempersepsikan pemikirannya dari apa yang dilihat dan didengar. Hasil dalam penelitian ini adalah pada tahun 2019 animo masayarakat khususnya warga keturunan Tionghoa memiliki antusisias yang sangat tinggi berkaitan dengan berita calon kandidat Presiden dan wakil Presiden tahun 2019, hal ini dibuktikan dengan hasil wawancara yang dilakukan serta observasi, yang menunjukan persepsi serta pandangan Warga keturunan Tionghoa yang paham tentang kandidat yang akan bertarung pada kontestasi Pemilu tahun 2019.
\end{abstract}

Kata Kunci: Persepsi,Etnis Tionghoa, Pemilu 2019, Media Televisi.

\section{PENDAHULUAN}

Tahun politik 2019 telah dimulai dengan digelarnya pemilihan umum secara langsung untuk memilih wakil legislatif baik pusat maupun daerah dan hasil telah ditetapkan, hasil pemilu legislatif menempatkan partai demokrasi indonesia perjuangan di urutan pertama dengan hasil perolehan suara yang tidak begitu signifikan.

$$
\text { Lobi - lobi politikpun telah di }
$$
lancarkan oleh para elite politik ataupun kandidat calon presiden yang di usung masing - masing partai seperti Joko widodo dari partai demokrasi indonesia perjuangan, Prabowo dari partai 


\section{Sabbhata Yatra}

Jurnal Pariwisata dan Budaya

Volume 1 Nomor 2 Desember 2020

Gerakan indonesia raya ( Gerindra ).

Untuk membentuk koalisi partai dan membawa misi bersama partai yang tergabung dalam koalisi tersebut.

Tentunya akan menjadi sebuah kajian yang menarik ketika melihat komposisi koalisi partai yang bergabung dalam kedua kubu koalisi yang terbentuk. Kedua kubu koalisi yang terbentuk memeiliki media yang mendukung dalam melancarkan propaganda dan kampanye untuk memikat hati pemilik suara terutama mereka yang mengkonsumsi media baik cetak ataupun elektronik. Melihat koalisi partai yang terbentuk, dimana pemilik media juga turut serta dalam koalisi partai tersebut sehingga media tidak lagi idependen dalam memberitakan calon kandidat yang ada.

Melihat dari apa yang menjadi kecondongan dari media yang tidak lagi independen maka bagaimana pengaruhnya terhadap khalayak untuk menentukan pilihan suaranya, Dengan pemberitaan yang begitu padat mengenai calon presiden yang diusung oleh masing - masing koalisi partai. Seperti yang di ungkapkan oleh Pawito, dalam konteks pemilu, misalnya media massa harus dapat melakukan berbagai hal, seperti mengoinformasikan kepada publik secara jujur, akurat dan fair mengenai pilihan - pilihan politis yang ada, meyakinkan kepada publik bahwa pemilihan umum merupakan momentum yang sangat penting untuk secara bersama - sama menentukan arah dan masa depan bangsa, segera memberikan penonjolan terhadap gagasan - gagasan solusif ketika ada gelagat konflik akan mengalami eskalasi. ( Pawito: 2009: 103 ).

Koalisi yang terbentuk membuat pemeberitaan media terutama televisi tidak lagi terlihat independen dan memberikan kejujuran seperti apa yang diungkapkan oleh Pawito dalam bukunya. Sehingga khalayak atau masyarakat akan sangat sulit untuk memilih media mana yang dapat dijadikan rujukan untuk dapat memberikan referensi yang baik dalam menentukan pilihan. Pemberitaan media yang lebih condong terhadap kandidat tertentu tentunya akan berimbas secara kognitif terhadap khalayak yang menkonsumsi media tersebut.

Masyarakat atau khalayak yang mengkonsumsi pemberitaan media yang condong kepada salah satu kandidat akan membuat sebuah dilema baru 


\section{Sabbhata Yatra}

Jurnal Pariwisata dan Budaya

Volume 1 Nomor 2 Desember 2020

dalam menentukan pilihan. Bagi calon kandidat tentunya media akan sangat membantu untuk memberikan pengaruh dan menyatakan visi serta program yang akan di jalankan ketika ia mendapatkan suara khalayak. Melihat masyarakat indonesia yang sangat beragam ( Plural ) tentunya pemberitaan media terutama Televisi juga telah di seting sesuai dengan karakter masyarakat indonesia yang plural.

Penerimaan khalayak terhadap pemberitaan media juga akan membuat khalayak lebih pintar dengan menganalisa dan mengenali sosok dan figur yang akan dipilihnya, ketika melihat sentimen masyarakat terhadap pribadi dan latar dari kandidat calon yang di usung oleh masing - masing koalisi akan menjadi hal menarik sejauh mana pemberitaan media mempengaruhi persepsi khalayak terhadap kandidat yang ada.

Khalayak atau masyarakat yang mengkonsumsi pemberitaan media tentunya memiliki latar belakang yang beraneka ragam dan majemuk sehingga akan memunculkan persepsi yang berbeda dan berbagai maccam pilihan dan pendapat yang muncul mengenai sosok kandidat yang diusung koalisi partai masing - masing. Seperti halnya masyarakat Tionghoa yang ada di surakarta tentunya memiliki persepsi tersendiri terhadap calon kandidat yang ada dengan melihat pemberitaan media terutama televisi sehingga dapat mempengaruhi pilihan dari masyarakat tionghoa yang ada di Surakarta. Masyarakat tionghoa yang ada di Surakarta memiliki populasi yang tidak sedikit dan keberadaan masyarakat Tionghoa juga sudah di akui sejak lama oleh keratonan Surakarta, hal ini dapat dilihat dari pemukiman masyarakat tionghoa yang ada di surakarta yang sering disebut dengan kampung Pecinan.

Melihat populasi masyarakat tionghoa yang ada di Surakarta yang memiliki jumlah yang tidak sedikit tentunya akan menjadi sebuah kajian study yang cukup menarik dengan melihat latar belakang yang ada dan tentunya media yang berperan dalam menggiring persepsi masyarakat terhadap kandidat calon presiden yang ada. Bukti diakuinya keberadaan masyarakat Tionghoa oleh Pihak kerton surakarta dengan diberikannya Hibah tanah untuk tempat peribadatan warga Tionghoa ( Klenteng ) ada dua tempat 


\section{Sabbhata Yatra}

Jurnal Pariwisata dan Budaya

Volume 1 Nomor 2 Desember 2020

yaitu Klenteng pasar Gede dan Klenteng yang berada di daerah Coyudan Surakarta. Masyarakat tionghoa yang ada di surakarta ketika dilihat latar belakang mata pencahariannya sebagai pedagang tentunya hal tersebut menjadi sebuah aspek untuk melihat bagaimana persepsipnya terhadap calon presiden yang ada dengan melihat perkembangan ekonomi dan perdagangan yang ada di daerah surakarta.

Tempat Ibadah Tridharma ( TITD ) Poo An Kiong yang berada di coyudan merupakan tempat dimana banyak terdapat masyarakat Tionghoa yang melaksanakan ibadah keagamaan dan tradisi. Banyak masyarakat Etnis Tionghoa yang menetap di daerah tersebut atau hanya sekedar membuka toko di daerah itu. Menjadi tempat yang tepat ketika mencari sumber yang berkenaan dengan persepsi masyarakat tionghoa terhadap kandidat calon presiden yang ada. Sebagai masyarakat indonesia tentunya masyarakat Tionghoa yang ada di TITD Poo An Kiong juga memiliki hak suara dan pilihan kandidat yang sesuai dengan apa yang diharapkan, lalu bagaimana media telah memberikan referensi pilihan dan bagaimana masyarakat atau khalayak mengenali kandidat dari pemeberitaan media terutama televisi.

Melihat potensi kandidat yang ada serta latar belakang pendidikan, ekonomi, agama tentunya akan menjadi faktor yang dapat memberikan gambaran bagi para pemilih terurtama masyrakat tionghoa yang memiliki hak suara dalam pemilu tahun 2019. Peran media terutama telivisi dalam mengenalkan para calon kandidat juga menjadi aspek penting dalam kajian penelitian ini.

\section{Media Televisi Sebagai Sumber Berita}

Perkembangan teknologi yang semakin berkembang menuntut media untuk memberikan informasi yang cepat dan akurat terhadap masyarakat. Media massa terutama surat kabar, majalah, radio dan televisi umumnya diyakini merupakan bagian yang penting dalam sistem politik demokrasi. Dengan media yang ada partai politik lebih mudah untuk mengenalkan partainya dan visi misi serta calon kandidatnya kepada masyarakat pemilih. Dalam era keterbukaan informasi dan telah disahkannya undang - undang tentang keterbukaan informasi media 


\section{Sabbhata Yatra}

Jurnal Pariwisata dan Budaya

Volume 1 Nomor 2 Desember 2020

diwajibkan memberikan informasi yang benar kepada masyarakat. Media massa juga memainkan peran - peran penting dalam masa kampanye politik seperti yang terjadi pada masa tahun politik 2019 dimana banyak bertebaran iklan dan pemberitaan tentang calon kandidat dan partai politik.

Media massa terutama televisi juga menyediakan forum untuk tempat terseklenggaranya debat kandidat yang di publikasikan dan dapat dilihat langsung oleh masyarakat sehingga masyarakat dapat dengan mudah menilai bagaimana visi dan misi serta program - program yang akan diberikan oleh para kandidat calon presiden. Media masa selalu hadir dengan memberikan informasi dan memberi warna tersendiri dalam kehidupan politik demokrasi di indonesia sehingga kehadirannya tidak dapat diabaikan begitu saja.

Peran penting media massa pada masa kampanye politik berlangsung, terjadi terutama selama periode kampanye dimana para calon kandidat capres ataupun partai berlomba - lomba untuk mendapatkan simpati masyarakat sehinga dapat memperoleh suara rakyat sebanyak - banyaknya. Strategi politik dalam konteks kampanye pemilihan umum tidak dapat dipisahkan dengan media massa. Strategi politik membutuhkan media massa supaya publik dapat mengetahu dan mendukungnya. Dan televisi merupakan media yang paling luas dan cepat penyebaranya.

\section{Etnisitas}

Dalam kehidupan masyarakat golongan atau kelompok - kelompok masyarakat sering kali membentuk koloni atau kelompok sehingga menimbulkan citra yang muncul dalam kelompok tersebut. Menurut em zul fajri dalam kamus lengkap bahasa indonesia bahwa etnis berkenaan dengan kelompok sosial dalam sistem sosial atau kebudayaan yang mempunyai arti atau kedudukan karena keturunan, adat, agama, bahasa dan sebagainya. Sedangkan menururt ariyuno sunoyo kamus Antropologi ( 1989 ), bahwa “ etnis merupakan suatu kesatuan budaya dan teritorial yang tersusun rapi dan dapat digambarkan ke dalam suatu peta etnografi"”.

Setiap kelompok memiliki batasan-batasan yang jelas untuk memisahkan antara satu kelompok etnis dengan etnis lainnya. Menurut 


\section{Sabbhata Yatra}

Jurnal Pariwisata dan Budaya

Volume 1 Nomor 2 Desember 2020

Koentjaraningrat, konsep yang Dari beberapa macam tercakup dalam istilah etnis adalah golongan manusia yang terikat oleh kesadaran dan identitas akan kesatuan kebudayaan, sedangkan kesadaran dan identitas seringkali dikuatkan oleh kesatuan bahasa juga (Koentjaranigrat, $1982: 58)$.

Etnisitas secara substansial
bukan sesuatu yang ada dengan
sendirinya tetapi keberadaannya terjadi
secara bertahap. Etnisitas adalah
sebuah proses kesadaran yang
kemudian membedakan kelompok kita dengan mereka. Basis sebuah etnisitas adalah berupa aspek kesamaan dan kemiripan dari berbagai unsur kebudayaan yang dimiliki, seperti misalnya adanya kesamaan dan kemiripan dari berbagai unsur kebudayaan yang dimiliki, ada kesamaan struktural sosial, bahasa, upacara adat, akar keturunan, dan sebagainya. Berbagai ciri kesamaan tersebut, dalam kehidupan sehari-hari tidak begitu berperan dan dianggap biasa. Dalam kaitannya, etnisitas menjadi persyaratan utama bagi munculnya strategi politik dalam membedakan "kita" dengan "mereka" (Ivan Hadar, 2000).

argumentasi menganai etnis tersebut di atas, dapat ditarik benang merah bahwa yang mana etnis adalah sebuah komunitas masyarakat yang memiliki berbagai macam kesamaan dalam kehidupan sosio-kulturalnya, kesamaan tersebut yang membedakan mereka dengan komunitas-komunitas lainnya dalam masyarakat. Olehnya itu yang muncul dalam kehidupan seharihari lebih menjurus pada pengklaiman "keakukan dan kekitaan"

\section{Persepsi}

Manusia memiliki pemikiran dan carapandang serta penilaian terhadap apa yang dilihat dan nampak oleh mata dan penglihatannya. Manusia memppunyai kecenderungan untuk mengadakan penilaian ( Judgement ) atau membangun kesan ( impression ) tentang orang - orang, situasi - situasi ataupun peritiwa - peristiwa yang terdapat di sekitar mereka. Dari penilaian yang terbentuk kemudian berpikir tentang suatu hal atau melakukan hal yang berhubungan dengan segala sesuatu yang dilihat didengar atau dirasakan. Dalam menangkap pesan dari suatu proses komunikasi, setiap individu tersebut 


\section{Sabbhata Yatra}

Jurnal Pariwisata dan Budaya

Volume 1 Nomor 2 Desember 2020

akan menaggapinya secara berbeda beda sesuai dengan keadaan individu tersebut sehingga menimbulkan persepsi yang berbeda pula. Manusia mempersepsikan segala hal yang terjadi di dunia dan hasil persepsi itu dapat memberikan pengaruh - pengaruh tertentu ke dalam diri individu itu sendiri maupun individu yang lainnya.

\section{Persepsi adalah pengindraan} terhadap suatu kesan yang timbul dalam lingkungannya pengindraan tersebut dipengaruhi oleh pengalaman, kebiasaan dan kebutuhan ( Efenddy, 2004:197 )

Menurut Dedy mulyana, persepsi adalah inti dari komunikasi, sedangkan penafsiran ( intrepetasi ) adalah inti dari persepsi yang identik dengan penyandian balik ( decoding) dalam proses komunikasi. Persepsi terdiri dari tiga aktivitas yaitu : seleksi, organisasi dan intrepetasi ( Mulyana, 2007 : $180-181$ ). Lebih lanjut lagi Deddy Mulyana ( 2007: 179 ) mendefinisikan persepsi sebagai proses internal yang memungkinkan kita memilih, mengorganisasikan dan menafsirkan rangsangan dari lingkungan kita, dan proses tersebut mempengaruhi perilaku kita.
Dalam buku pengantar ilmu komunikasi oleh Hafied cangara ( 2007: 162 ) dijelaskan bahwa persepsi ialah dimana seseorang menyadari adanya obyek yang menyentuh salah satu pancainderanya, apakah itu mata atau telinga. Persepsi terbentuk karena adanya rangsangan yang diorganisasi kemudian diberi interpretasi menurut pengalaman, budaya dan tingkat pengetahuannya.

Definisi lain tentang persepsi yang dapat dijumapi misalnya dari Berelson dan Steiner ( 1964 ) sebagaimana dikutip oleh Severin dan Tankard Jr. ( 1988: 121 ) yang menyatakan bahwa persepsi merupakan sebuaj complex process by which people select, organize and interpret sensory into a meaningful and coherent picture of the world. Kemudian definisi ini menimbulkan argument yang dikeluarkan olegh Severin dan Tankard Jr. Bahwa individu - i9ndividu pada dasarnya tidak bersifat pasif, tetapi bersifat aktif dalam proses persepsi. Mereka juga berpendapat bahwa beberapa faktor psikologis, seperti asumsi, motivasi, penghargaan terhadap nilai - nilai budaya , minat dan sikap ikut serta mempengaruhi persepsi. 
$\begin{array}{rlll} & \text { Pengertian } & \text { persepsi } & \text { seringkali } \\ \text { juga disamakan } & \text { dengan } & \text { pengertian }\end{array}$ respon, reaksi tingkah laku yang merupakan akibat dari stimulus sosial ( gejala sosial ) yang berupa perubahan nilai yang timbul di tengah - tengah masyarakat. Dalam hal ini, nilai yang muncul tersebut menentukan respoin yang diambil sebagai landasan pokok perbuatan atau bertindak seperti pendapat yang dikemukakan oleh soerjono Soekamto, bahwa interaksinya dengan perorangan/kelompok masyarakat terlihat adanya, serta mengandung rangsangan dan respon ( Soekamto, 1975: 56-60 ).

Persepsi merupakan aktifitas menilai sehingga bersifat evaluatif dan subyektif. Evaluatif berkaitan dengan nilai baik - buruk atau positif - negatif. Subyektif berarti adanya perbedaan kapasitas indrawi dan perbedaan filter konseptual dari masing - masing individu dalam melakukan persepsi. Sehingga pengolahan stimuli dalam komunikan atau khalayak akan menbuahkan makna yang eksklusif yang bertbeda antara satu dengan yang lainnya.

$$
\text { Berkenaan dengan persepsi }
$$
pemilih terhadap pemeberitaan politik para kandidat calon presiden, Nursal ( 2004: 234 ) yang mengadaptasi Kotler ( 1995 ) dan peter Olson ( 1993 ), menyebutkan ada bebrapa tahap respon yang dilakukan oleh pemilih dalam hal pemilihan umum terhadap stimulasi pembritaan politik dan kandidatnya, yaitu :

1. Awarenes, yakni bila seseorang dapat mengingat atau menyadari bahwa sebuah pihak tertentu merupakan sebuah kontestan pemilu. Dengan jumlah kontestan pemilu yang banyak, membangun awarene cukup sulit dilakukan, khususnya bagi partai - partai. Sehingga akan mempersulit para khalayak untuk mengetahui kontestan yang bertarung dalam pemilu. Khalayak akan lebih condong kepada kandidat yang memiliki brand awareness.

2. Knowledge, yakni ketika seseorang pemilih mengetahui bebrapa unsur penting mengenai politik kentestan tersebut, baik 
secara substansi maupun presntasi. Dalam tahap ini para kandidat lebih dikenal dalam benak khalayak sehingga membentuk makna politi tertentu dalam benak khalayak. Dalam pemasaran produkl komersial tahap ini disebut juga sebagai tahap pembentuk brand association dan perceived quality.

3. Liking, yakni tahap dimana seorang pemilih menyukai kontestan tertentu karena satu atau lebih makna politis yang terbentuk di pikirannya sesuai dengan aspirasinya.

4. Preference, tahap dimana pemilih menganggap bahwa satu atau beberapa makna politis yang terbentuk sebagai interpretasi terhadap produk politik sebuah kontestan tidak dapat dihasilkan secara lebih memuaskan oeleh kontestan lainnya. Dengan demikian pemilih tersebut memiliki kecenderungan untuk memilih kontestan tersebut.

5. Conviction, pemilih tersebut sampai pada keyakinan untuk memilih kontestan tertentu.

\section{METODE}

Dalam penelitian ini menggunakan metode deskriptif kualitatif yaitu metode penelitian untuk membuat gambaran mengenai situasi atau kejadian ( Nazir: 2003 ). Jenis penelitian ini memberikan peluang yang besar akan munculnya interpretasi interpretasi alternatif. Metode ini juga mampu mendekatkan antara peneliti dengan objek yang dikaji. Cara kerja penelitian ini berlangsung serempak dan dilakukan dalam bentuk pengumpulan, pengolahan dan menginterpretasikan sejumlah data yang bersifat kualitatif. Menurut nawawi ( Nawawi: 1995 ), penelitian deskriptif terbatas pada usaha mengungkapkan suatu masalah atau keadaan atau peristiwa sebagaimana adanya sehingga bersifat sekedar untuk mengungkapkan fakta ( fact finding). Hasil penelitian ditekankan pada memberikan gambaran secara obyektif tentang keadaan sebenarntya dari obyek yang diselidiki. Akan tetapi guna mendapatkan manfaat yang lebih luas dalam penelitian ini, kerap kali disamping pengungkapan fakta sebagaimana adan6ya dilakukan juga 


\section{Sabbhata Yatra}

Jurnal Pariwisata dan Budaya

Volume 1 Nomor 2 Desember 2020

interpretasi - interpretasi yang kuat. Rakhmat ( 1993: 24 ) menyatakan bahwa penelitian deskriptif hanyalah memaparkan situasi atau peristiwa. Penelitian ini tidak mencari atau menjelaskan hubungan, tidak menguji hipotesis atau membuat prediksi.

Penelitian ini memberikan gambaran bagaimana persepsi etnis Tionghoa di TITD setelah melihat pemebritaan politik tanpa menggunakan uji hipotesis atau prediksi. Dimana oinformasi diperoleh dengan membandingkan hasil wawancara dari masing - masing responden, observasi dan kajian kep[ustakaan, baru kemudian menarik dan menyimpulkannnya dari persepsi responden.

Dalam penelitian ini digunakan populasi yang merupakan seluruh obyek atau subyek dengan karakterisitik tertentu yang akan doiteliti ( Alimul, 2007 ). Populasi dari penelitian ini adalah Umat Tempat Ibadah Tridharma ( TITD ) Po An Kiong Surakarta yang merupakan masyarakat yang memiliki hak suara dalam pemilu tahun 2019 yang berusia sekitar 25 - 60 tahun yang memjadi pengurus, anggota dan umat di TITD Po An Kiong Surakarta.
Sampel dalam penelitian ini adalah bagian dari populasi yang akan diteliti atau sebagian jumlah karakteristik yang dimiliki oleh populasi ( Alimul, 2007). Peneliti menggunakan rancangan pengambilan sampel dengan purposive sampling, yaitu memilih orang - orang tertentu karena peneliti menganggap bahwa seseorang tersebut memiliki informasi yang diperlukan bagi penelitian. Jumlah sampel dalam penelitian ini adalah 20 orang responden yang merupakan umat TITD Poo An Kiong Surakarta.

\section{HASIL PEMBAHASAN}

Berdasarkan catatan sejarah yang ditulis oleh seorang wartawanastologer yang ternama empeh wong kam fu alias wongsorejo dalam sebuah buku cetak yang berjudul "riwayat klenteng/ vihara/ lithang se jawa", yang dicetak di percetakan sidoyoso, jl. Sidoyoso surabaya, telah mendapat izin persetujuan cetak / terbit no.pol.: 05/pers/iv/1980/intelpampol kota besar surabaya, tanggal 3 april 1980, maka dapat diketahui dengan singkat tentang sejarah berdirinya klenteng "poo an kiong" surakarta.

Lokasi klenteng "poo an kiong” surakarta yang terletak di jalan 


\section{Sabbhata Yatra}

Jurnal Pariwisata dan Budaya

Volume 1 Nomor 2 Desember 2020

secoyudan surakarta, berdiri pada tgl 8 agustus tahun 1828 (masehi). Tanah tempat berdirinya klenteng merupakan tanah hibah yang diberikan oleh pihak keraton kasunanan surakarta hadiningrat, berdasarkan turunan kekancingan pepatih dalem ing ska anka 62a/ 211 tahun 1930, yang ditandatangani oleh pepatih kraton dalam ska, sastro Negoro. Didalam Nya Terdapat Tulisan Nama "Toa Pek Kong Kwee Sing Ong” Ing Secoyudan, Yang Identik Dengan Nama Dewa Tuan Rumah Nya.

$\begin{array}{rlll}\text { Pelopor } & \text { Dari Klenteng Ini } \\ \text { Adalah Tjan } & \text { Kong Bok, Yang }\end{array}$
Kemudian Diteruskan Oleh Kapiten Kwee Tjien Gwan. Pada Umumnya Sebuah Klenteng Dibangun Dengan Semangat Gotong Royong Dari Leluhur-Leluhur Masyarakat Etnis Tionghoa Itu Sendiri. Hal Ini Masih Dapat Kita Temukan/ Buktikan Melalui Pahatan Nama-Nama Penyumbang/ Donatur Yang Diukir/ Dipahat, Baik Yang Terdapat Di Meja-Meja Altar Persembahan, Dibagian OrnamenOrnamen Klenteng, Maupun Di Tempat-Tempat Lainnya, Yang Membuktikan Dengan Sangat Jelas,
Siapa Nama Penyumbang/ Donatur Nya, Sekaligus Tahun Pembuatan Nya.

Selama masa kampanye di tahun politik 2019 sering kali pemeberitaan media terutama televisi menjadi konsumsi masyarakat setiap hari. Perkembangan demokrasi yang terjadi di indonesia membuat masyarakat lebih perduli akan perkembangan politik yang terjadi sehingga media televisi berlomba - lomba untuk memberitakan kandidat kandidat yang akan bertarung dalam pemilihan presiden dan wakil presiden.

Pemberitaan media televisi seringkali memperlihatkan sosok kandidat dengan gamblang dan jelas termasuk profil, visi dan misi serta program yang akan dijalankan sehingga masyarakat dapat melihat secara langsung sosok kandidat yang akan dipilih nantinya. Dengan melihat perkembangan media dan pemberitaan politik serta kepemilikan media yang lebih condong kepada kandidat tertentu sehingga saat ini jarang ditemukan media terutama televisi yang bersifat independen sehingga isi pemberitaan yang terdapat dalam pemberitaanpun terkadang lebih terlihat memihak terhadap satu kandidat saja. 
Dengan pemberitaan yang ada tentunya kandidat akan di kenal secara luas oleh masyarakat, kesempatan untuk dapat terpilih dan mendapatkan suara rakyat akan terbuka lebih lebar. Berita dan pemberitaan media merupakan salah satu bentuk komunikasi yang efektif yang dapat dengan mudah diterima oleh masyarakat luas. Terutama jika melihat dan meninjau fungsi uatam media untuk komunikasi massa persuasif, pemberitaan media televisi sangat strategis untuk mendapatkan hati masyarakat apalagi pemberitaan itu bersifat positif.

Pemberitaan media televisi tentang sosok kandidat baik pemberitaan negatif ataupun positife membuat partisipan lebih bisa menilai kualitas kandidat yang ada dengan melihat informasi dan isi berita dalam pemberitaan media televisi. Pemberitaan yang bersifat menyerang atau menjatuhkan kandidat yang lain membuat masyarakat akan membandingakan track record kinerja antara kandidat yang satu dengan yang lainnya dengan kandidat yang diserang atau dijatuhkan. Sedangkan pemberitaan yang bersifat positif yang berkutat dalam pembentukan pencitraan hanya memperlihatkan sisi baik kandidat, cenderung memanipulasi persepsi pemilih etnis Tionghua, sehingga partisipan hanya akan menyerap isi pemberitaan informasi dan hal - hal yang bersifat positif saja yang menyangkut kandidat, sehingga membuat partisipan bersifat pasif dan menerima begitu saja pencitraan yang dibentuk oleh pemberitaan dan media televisi tersebut dan dianggap sebagai realitas yang sebenarnya. Pengamatan penulis yang menyangkut pemberitaan positife umumnya lebih dianggap menarik daripada pemberitaan yang menjatuhkan atau negatif.

Dari persepsi - persepsi yang muncul yang diutarakan para partisipan yang terlihat ada beberapa poin yang menjadi catatan peneliti. Ada kecenderungan yang menunjukan bahwa persoalan yang sering dibicarakan adalah visi dan misi dan latar belakang kandidat. Ketika mempersepsikan pemberitaan media televisi yang ada kalangan etnis Tionghoa yang ada di TITD Poo An Kiong cenderung lebih detail dalam memberikan penilaian mereka, dalam arti bagaimana menilai isi pemberitaan yang menyangkut kandidat dengan 


\section{Sabbhata Yatra}

Jurnal Pariwisata dan Budaya

Volume 1 Nomor 2 Desember 2020

kaitannya kinerja kandidat bagi kemajuan bangsa indonesia. Latar belakang kandidat juga menjadi faktor penting yang dilihat oleh partisiapn dalam melihat pemberitaan media televisi. Sosok dan profil kandidiat terutama yang dalam pemberitaan memiliki track record yang baik serta bersih dianggap sebagai sosok yang cocok untuk memipin negara kedepannya. Selain isu ekonomi dan masalah kehidupan juga dilihat bagaimana sumber daya alam yang ada di negara ini dikelola dengan baik dan maksimal sehingga dapat dinikmati oleh seluruh rakyat indonesia.

Isu yang tidak kalah menarik yang diungkapkan oleh partisipan adalah menyangkut berita - berita yang negatife yang diberitakan oleh media televisi yang menyangkut latar belakang kehidupan para calon kandidat yang ada. Isu pelanggaran HAM sangat melekat pada sosok kandidat nomor urut dua yaitu Prabowo Subianto ia dianggap paling bertanggung jawab dengan pelanggaran HAM yang terjadi di indonesia pada tahun 1998 yang mengakibatkan banyak aktifis yang hilang.
Sifat kedaerahan juga sangat menonjol dari para partisipan dengan melihat sosok kandidat nomor urut satu yang berasal dari surakarta, sehingga para partisipan merasa memiliki histori dan kedekatan dengan kandidat Joko Widodo. Hal ini yang membuat para partisipan memberikan pendapat yang hampir semua positive mengenai kandidat yang mendapatkan nomor urut satu tersebut.

\section{PENUTUP}

Dalam penelitian ini diperoleh kesimpulan bahwa persepsi Etnis Tionghoa terhadap pemberitaan kandidat Capres dan Cawapres yang ditayangkan di media televisi pada pemilu tahun 2019 sangat bervariasi. Namun kecenderungan persepsi pemilih Etnis Tionghoa di TITD Poo An Kiong lebih melihat kinerja, latar belakang kandidat serta track record serta visi dan misi yang disampaikan. Dalam perkembangannya partisipan juga membandingkan antara media televisi yang satu dengan yang lainnya yang menyangkut pemberitaan yang bersifat menjatuhkan kandidat yang lain terutama isu - isu yang berkembang dalam pemberitaan media televisi. 
Persepsi pemilih Etnis Tionghoa Di TITD Poo An Kiong mengenai pengaruh pemberitaan politik di media televisi terhadap keputusan memilih sangat mengarah pada satu kandidat dengan melihat latar belakang dan track record serta pencitraan yang ada dalam pemberitaan media televisi. Sehingga bisa disimpulkan bahwa pengaruh pemberitaan media sangat besar dalam memberikan informasi yang menyangkut kandidat yang ada.

\section{DAFTAR PUSTAKA}

A.Alimul Hidayat. 2007. Metode Penelitian Kebidanan Dan Tehnik Analisis Data. Surabaya: Salemba

Adnan Nursal. 2004. Political Marketing : Strategi Memenangkan Pemilu. Jakarta: Gramedia Pustaka Utama.

TITD Poo An Kiong. Anggaran Dasar Dan Anggaran Rumah Tangga, Tahun 2009

Antara News.com. Profil Kandidat Capres 2019

Ariyuno Sunoyo, $1985 . \quad$ Kamus Antropologi, Jakarta, Antropologi Press

Cangara, Hafied. 2007. Pengantar Ilmu Komunikasi. Jakarta: PT. Raja Grafindo Persada.
Efenfendy. (2004 ). Ilmu Komunikasi Teori dan Praktek. Bandung: Remaja Rosdakarya.

Ivan, A, Hadar, "Etnisitas dan Negara Bangsa”, Kompas, 29 Mei 2000.

Koentjaranigrat, 1982. Manusia dan Kebudayaan di Indonesia, Jakarta: Penerbit Djambatan

Merdeka.com. Profil Kandidat Capres dan Cawapres 2019

Moh. Nazir. (2003), Metode Penelitian,Cetakan Keempat, Jakarta: Ghalia Indonesia

Mulyana, Deddy. 2007. Ilmu Komunikasi: Suatu Pengantar. Bandung : Remaja Rosdakarya.

Nawawi, Hadari. 1995. Metode Penelitian Bidang Sosial. UGM Press. Yogyakarta.

Nazir, Moh. (2003). Metode Penelitian Sosial. Jakarta:PT Bina Aksara.

Pawito, Komunikasi Politik, Media Massa dan Kampanye Pemilihan, JALANSUTRA, Yogyakarta \& Bandung, 2009.

Pawito, Penelitian Komunikasi Kualitatif, LkiS, Yogyakarta, 2007.

Punch, K. F. (1998). Research, Quantitave and Introduction to Social Qualitative Approach. British : SAGE Publication

Rakhmat, Jalalludin, Metode Penelitian Komunikasi, PT. Remaja Rosdakarya, Bandung, 2004. 


\section{Sabbhata Yatra}

Jurnal Pariwisata dan Budaya

Volume 1 Nomor 2 Desember 2020

Severin, Werner J dan James W.Tankard. 1988. Teori

Komunikasi. Kencana. Jakarta.
Soekanto, Soerjono. (2004). Sosiologi Suatu Pengantar.Jakarta: Raja Grafindo Persada 